\title{
Review
}

\section{Functions of PPR Proteins in Plant Growth and Development}

\author{
Xiulan Li *, Mengdi Sun, Shijuan Liu, Qian Teng, Shihui Li and Yueshui Jiang * \\ School of Life Sciences, Qufu Normal University, Qufu 273165, China; sunzhuzhu12138@163.com (M.S.); \\ sjliusj@163.com (S.L.); T19819061626@163.com (Q.T.); lshih4030@163.com (S.L.) \\ * Correspondence: xiulanli@qfnu.edu.cn (X.L.); jiangyueshui@qfnu.edu.cn (Y.J.)
}

check for updates

Citation: Li, X.; Sun, M.; Liu, S.; Teng, Q.; Li, S.; Jiang, Y. Functions of PPR Proteins in Plant Growth and Development. Int. J. Mol. Sci. 2021, 22, 11274. https://doi.org/10.3390/ ijms222011274

Academic Editors:

Alexandre Smirnov and Sarath Janga

Received: 16 September 2021

Accepted: 16 October 2021

Published: 19 October 2021

Publisher's Note: MDPI stays neutral with regard to jurisdictional claims in published maps and institutional affiliations.

Copyright: (c) 2021 by the authors. Licensee MDPI, Basel, Switzerland. This article is an open access article distributed under the terms and conditions of the Creative Commons Attribution (CC BY) license (https:// creativecommons.org/licenses/by/ $4.0 /)$.

\begin{abstract}
Pentatricopeptide repeat (PPR) proteins form a large protein family in land plants, with hundreds of different members in angiosperms. In the last decade, a number of studies have shown that PPR proteins are sequence-specific RNA-binding proteins involved in multiple aspects of plant organellar RNA processing, and perform numerous functions in plants throughout their life cycle. Recently, computational and structural studies have provided new insights into the working mechanisms of PPR proteins in RNA recognition and cytidine deamination. In this review, we summarized the research progress on the functions of PPR proteins in plant growth and development, with a particular focus on their effects on cytoplasmic male sterility, stress responses, and seed development. We also documented the molecular mechanisms of PPR proteins in mediating RNA processing in plant mitochondria and chloroplasts.
\end{abstract}

Keywords: PPR protein; cytoplasmic male sterility; seed development; RNA editing; RNA splicing

\section{Introduction}

Pentatricopeptide repeat (PPR) proteins are characterized by the presence of tandem arrays of a degenerate 35-amino-acid repeat motif, PPR motif [1]. Based on the types of motif and their arrangement, PPR proteins are divided into two classes, P and PLS. P-class proteins only contain canonical P-motifs with 35 amino acids, whereas PLS-class proteins consist of P-, L- (35 or 36 amino acids), and S- (31 or 32 amino acids) motifs forming tandemly repeated PLS triplets [2]. Many of the PLS-class proteins are carboxyl terminally extended with highly conserved E, E+, or DYW domains. Thus, PLS-class proteins can be further divided into PLS, E, E+, and DYW subclasses according to the domains identified in carboxyl terminal [3].

PPR proteins are sequence-specific RNA-binding proteins that are mostly localized to mitochondria and/or chloroplasts, where they are involved in RNA post-transcriptional processing [4] (Figure 1A). In general, the P-class PPR proteins mediate diverse aspects of RNA processing in plant organelles, while the PLS-class PPR proteins mainly function in RNA editing [5]. Mutations in these PPR protein-coding genes lead to the dysfunction of mitochondria and/or chloroplasts, thereby resulting in growth retardation, pollen abortion, and seed development defects in plants [4], indicating the important roles of PPR proteins in plant growth and development (Figure 1B). 


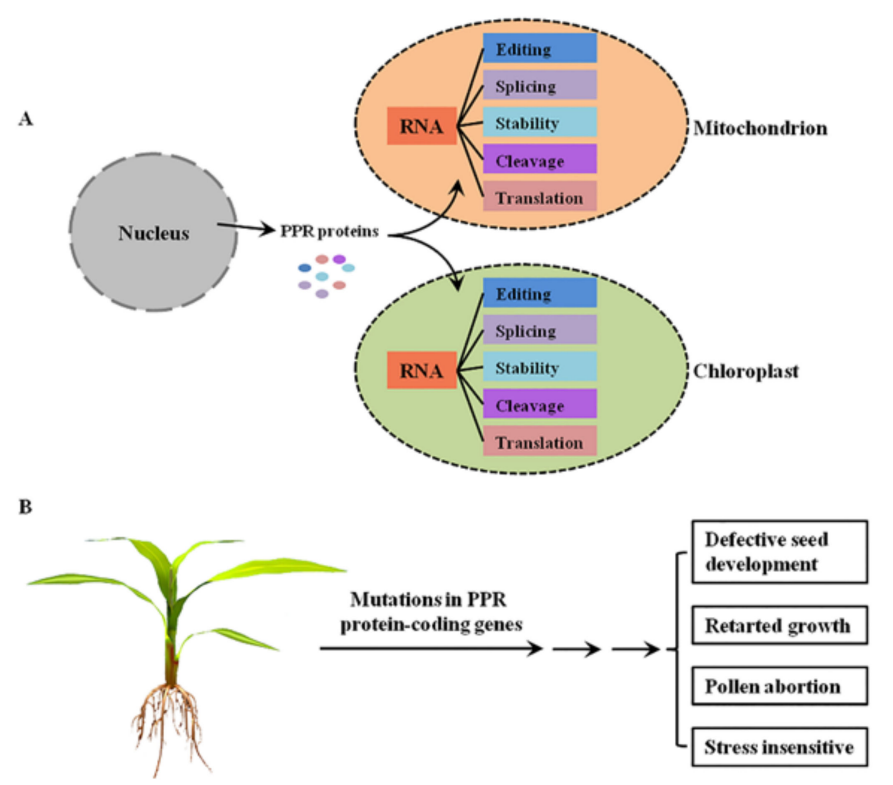

Figure 1. The functions of PPR proteins in plants. (A) The molecular functions of PPR proteins in plant mitochondria and chloroplasts. PPR proteins are encoded by nuclear genes, translated in the cytoplasm, and then imported into mitochondrion or chloroplast to mediate multiple steps of RNA processing. (B) The main growing and developmental phenotypes of plant mutants of PPR protein-coding genes.

\section{Functions of PPR Proteins in Cytoplasmic Male Sterility}

Cytoplasmic male sterility (CMS) is a maternally inherited trait that presents a defect in the production of viable pollen. CMS is widespread in higher plants, and has been widely used in the production of hybrid seeds and utilization of heterosis in many crop species [6,7]. Plant CMS is usually caused by mutations, rearrangements, or recombinations of mitochondrial DNA, and in many instances, male fertility can be restored specifically by restorer-of-fertility $(R f)$ genes in the nuclear genome [8,9]. To date, more than ten $R f$ genes have been cloned and functionally characterized in various crop species, and the majority of them were found to encode PPR protein, including Rf1a [10], Rf1b [11], Rf3 [12], Rf4 [13], $R f 5$ [14], Rf6 [15] in rice; Rfo [16], PPR-B [17], RsRf3-4 [18], Rfk1 [19] in radish; Rf1 [20], $R f 2$ [21] in sorghum; $R f p$ [22], $R f n$ [23] in rapeseed; Rf-PPR592 [24] in petunia; BrRfp1 [25] in Chinese cabbage; and Rfm1 [26] in barley. With the exception of the sorghum Rf1 [20] and the barely $R f m 1$ [26], the PPR-type $R f$ genes encode PPR proteins belonging to P class.

Members of P-class PPR proteins mostly function in various post-transcriptional process of organellar RNAs, such as RNA splicing, RNA stabilization, RNA cleavage, and translation $[4,5]$. Proteins encoded by $R f$ genes usually target mitochondria and act as fertility restorers by suppressing the production of mitochondrial CMS-inducing proteins [6,11]; however, the exact molecular mechanisms underlying fertility restoration by RF proteins is presently unclear. The PPR-type RF proteins have been proposed to rescue fertility by regulating the expression of CMS-conferring genes through the similar molecular mechanisms as that of other PPR proteins. In most of the CMS systems, PPRtype RF proteins bind to the mitochondrial CMS-conferring transcripts and promote their cleavage or degradation [27]. For example, rice RF1A and RF1B proteins, respectively encoded by Rf1a and Rf1b genes, have been considered to restore CMS by processing mitochondrial orf 79 transcript via different mechanisms. RF1A directly binds to and cleaves the atp6-orf 79 transcript at the intercistronic region, whereas RF1B promotes the rapid degradation of the atp6-orf79 transcript $[10,11]$. The protein encoded by rice $R f 4$ gene was reported to suppress WA352-mediated male sterility by reducing WA352 transcript levels [13]. Two rice RF proteins, Rfp and Rfn, are involved in transcript cleavage of orf224 and orf222, respectively [22,23]. 
In some CMS systems, PPR-type RF proteins restore the male fertility by impeding the translation or post-translational processing of mitochondrial CMS-inducing proteins. Studies on radish PPR-B revealed that PPR-B protein does not function through cleavage or degradation of the orf $138 \mathrm{mRNA}$, but rather block its translation by inhibiting either the association with or the progression of mitochondrial ribosomes on the orf138 mRNA [17]. Similarly, rice RF3 protein does not affect the abundance of WA352 transcript but suppresses the accumulation of WA352 protein [12]. In addition, $R f 1$ from sorghum and $R f m 1$ from barely encode PPR proteins belonging to PLS class. As PLS-class PPR proteins almost exclusively play a role in RNA editing, it is possible that sorghum $R f 1$ and barely $R f m 1$ restore pollen fertility by editing S-orf transcripts or other target RNAs [8,26].

CMS was not only an ideal model system to study the interaction between mitochondrial and nuclear genomes but also a useful genetic tool for breeding to exploit hybrid vigor in crops [27]. Although PPR proteins are involved in the restoration of male fertility, functions of most PPR proteins are still obscure. Therefore, exploring the functions of PPR proteins will contribute to understanding the CMS mechanism and improving molecular breeding in crops.

\section{Functions of PPR Proteins in Plant Responses to Biotic and Abiotic Stresses}

In previous studies, PPR genes were found to change their expression patterns under biotic and abiotic stresses and regulate growth in many plants. For instance, in Arabidopsis, 11 PPR proteins have been shown to respond to biotic or abiotic stresses. SOAR1, a cytosolnucleus dual-localized PPR protein, is involved in ABA signaling and tolerance to drought, salt, and cold stress [28]. GUN1 is a chloroplast-located PPR protein, the gun1 mutant is defective in response to norflurazon, lincomycin, and high-light treatments [29], and it also exhibits a more susceptible phenotype to photooxidative stress caused during the de-etiolation [30]. In addition, nine mitochondria-located PPR proteins, MED11/LOI1 [31], PPR40 [32], ABO5 [33], PGN [34], AHG11 [35], SLG1 [36], SLO2 [37], PPR96 [38], and POCO1 [39] were reported to participate in responses to many abiotic or biotic stresses. In rice, two chloroplast-located PPR proteins, OsV4 and TCD10, are required for chloroplast development at early seedling stage under cold stress [40,41]. The chloroplast-located PPR protein WSL affects chloroplast development and abiotic stress response in rice, and the wsl mutant displays chlorotic striations early in development and enhanced sensitivity to ABA, salt, and sugar [42]. Recently, a mitochondrial PPR protein OsNBL3 was found to be involved in response to biotic or abiotic stresses. The $n b l 3$ mutant exhibits growth retardation, leaf wilting, and premature senescence, and it shows enhanced resistance against fungal and bacterial pathogens and to salt stress [43].

A few of the PPR proteins involved in plant responses to biotic and abiotic stresses have been shown to play roles in post-transcriptional processing of RNA in mitochondria and chloroplasts. In Arabidopsis, PGN participates in editing of mitochondrial cox 2 and nad6 [34]. SLG1 and AHG11 are involved in editing of mitochondrial nad3 and nad4, respectively $[35,36]$. SLO2 was found to be required for mitochondrial RNA editing at multiple sites [37]. In rice, WSL functions in the splicing of chloroplast rpl2 [42]. OsNBL3 takes part in the splicing of mitochondrial nad5 [43]. Although POCO1 encodes a mitochondrialocalized P-class PPR protein, multiple RNA editing defects were identified in poco1 mutant, which suggest that POCO1 may be required for RNA editing [39].

Under normal and stress conditions, retrograde signaling from organelles plays vital roles in coordinating the expression of nuclear and organellar genes, and in regulating plant growth and development. Arabidopsis GUN1 is identified to be a central integrator of chloroplast retrograde signaling pathways. In 2016, Tadini et al. revealed that GUN1 controls accumulation of the chloroplast ribosomal protein S1 at the protein level and interacts with proteins involved in chloroplast protein homeostasis [44]. MORF2 is an essential component of RNA editosome and is required for editing at almost all sites in chloroplast RNAs [45]. Unlike typical PPR proteins, GUN1 does not appear to bind to RNAs. However recently, GUN1 was found to physically interact with MORF2 to regulate 
the editing efficiency of multiple sites within chloroplast RNAs and modulate the activity of the nucleus-encoded chloroplast RNA polymerase, particularly during retrograde signaling [46,47], indicating that GUN1 is important for chloroplast RNA metabolism and chloroplast-to-nucleus retrograde communication. The mitochondrial PPR protein LOI1 of Arabidopsis was reported to be involved in RNA editing of mitochondrial transcripts cox3, nad4, and $c c b 203$, and regulate biosynthesis of isoprenoids, metabolites known to affect defense gene expression in response to wounding and pathogen infection [31]. The loil mutant has decreased sensitivity to two inhibitors of isoprenoid synthesis, fungal phytotoxin lovastatin, and herbicide clomazone, showing the indirect effects of retrograde signaling from mitochondria to the cytoplasm to evoke alteration of the mevalonate pathway [48]. Therefore, these results reveal a putative link between organellar RNA processing and plant responses to environmental stresses.

\section{Functions of PPR Proteins in Seed Development}

In angiosperm plants, seed development starts with double fertilization of egg and central cells with two sperm cells, which leads to the formation of a diploid embryo and a triploid endosperm, and develops into mature seeds comprising three structures: maternal coat, embryo, and endosperm [49]. Development of embryo and endosperm is well correlated and regulated by numerous distinct proteins involved in many important physiological processes [50], including cell growth, RNA transcription and post-transcriptional processing, etc.

In recent years, more and more genetic and biochemical studies have shown that PPR proteins play important roles in seed development of higher plants, and loss-offunction of these PPR proteins usually leads to defects in embryogenesis and/or endosperm development $[4,51]$. According to the phenotypic expression, seed mutants can be divided into four major classes: empty pericarp (emp), embryo specific (emb), defective kernel (dek), and small kernel (smk). A detailed summary of the maize and Arabidopsis seed mutants caused by the functional defects of PPR proteins is provided in Table 1.

Table 1. Selected functionally characterized PPR proteins essential for seed development in maize and Arabidopsis.

\begin{tabular}{|c|c|c|c|c|c|c|}
\hline Species & $\begin{array}{l}\text { Subcellular } \\
\text { Localization }\end{array}$ & $\begin{array}{c}\text { Mutant } \\
\text { Phenotype }\end{array}$ & $\begin{array}{l}\text { Protein } \\
\text { Name }\end{array}$ & $\begin{array}{l}\text { PPR } \\
\text { Class }\end{array}$ & Function(s) & References \\
\hline \multirow{27}{*}{ Maize } & Mitochondrion & dek & DEK2 & $\mathrm{P}$ & RNA splicing, nad 1 intron 1 & [52] \\
\hline & Mitochondrion & dek & DEK10 & PLS & RNA editing, nad3-61, 62, and cox2-550 & [53] \\
\hline & Mitochondrion & dek & DEK35 & $\mathrm{P}$ & RNA splicing, nad4 intron 1 & {$[54]$} \\
\hline & Mitochondrion & dek & DEK36 & PLS & $\begin{array}{l}\text { RNA editing, atp4-59, nad7-383, and } \\
\text { ccmFN-302 }\end{array}$ & {$[55]$} \\
\hline & Mitochondrion & dek & DEK37 & $\mathrm{P}$ & RNA splicing, nad2 intron 1 & [56] \\
\hline & Mitochondrion & dek & DEK39 & PLS & RNA editing, nad3-247 and nad3-275 & [57] \\
\hline & Mitochondrion & dek & DEK40 & PLS & $\begin{array}{c}\text { RNA editing, cox3-314, nad2-26, and } \\
\text { nad5-1916 }\end{array}$ & {$[58]$} \\
\hline & Mitochondrion & dek & $\begin{array}{l}\text { DEK41/ } \\
\text { DEK43 }\end{array}$ & $\mathrm{P}$ & RNA splicing, nad4 intron 1 and 3 & {$[59,60]$} \\
\hline & Mitochondrion & dek & DEK46 & PLS & $\begin{array}{c}\text { RNA editing, D5-C22 of nad7 intron } 3 \\
\text { and } 4\end{array}$ & [61] \\
\hline & Mitochondrion & dek & DEK53 & PLS & RNA editing, multiples sites & {$[62]$} \\
\hline & Mitochondrion & dek & DEK55 & PLS & $\begin{array}{l}\text { RNA splicing, nad4 intron } 1 \text { and 3;RNA } \\
\text { editing, multiple sites }\end{array}$ & {$[63]$} \\
\hline & Mitochondrion & dek & DEK605 & PLS & RNA editing, nad1-608 & {$[64]$} \\
\hline & Mitochondrion & smk & SMK1 & PLS & RNA editing, nad7-836 & [65] \\
\hline & Mitochondrion & $s m k$ & SMK4 & PLS & RNA editing, cox1-1489 & [66] \\
\hline & Mitochondrion & $s m k$ & SMK6 & PLS & $\begin{array}{l}\text { RNA editing, nad1-740, nad } 4 L-110 \text {, } \\
\text { nad7-739, and } m t t B-138,139\end{array}$ & {$[67]$} \\
\hline & Mitochondrion & $s m k$ & ZmSMK9 & $\mathrm{P}$ & RNA splicing, nad5 intron 1 and 4 & [68] \\
\hline & Mitochondrion & smk & PPR2263 & PLS & RNA editing, nad5-1550 and cob-908 & [69] \\
\hline & Mitochondrion & smk & MPPR6 & $\mathrm{P}$ & Translation, rps3 mRNA & [70] \\
\hline & Mitochondrion & dek/smk & PPR20 & $\mathrm{P}$ & RNA splicing, nad2 intron 3 & [71] \\
\hline & Mitochondrion & smk & PPR78 & $\mathrm{P}$ & RNA stabilization, nad5 mature mRNA & [72] \\
\hline & Mitochondrion & emp & EMP4 & $\mathrm{P}$ & Expression of mitochondrial transcripts & [73] \\
\hline & Mitochondrion & emp & EMP5 & PLS & RNA editing, multiple sites & [74] \\
\hline & Mitochondrion & emp & EMP7 & PLS & RNA editing, $c c m F N-1553$ & [75] \\
\hline & Mitochondrion & emp & EMP8 & $\mathrm{P}$ & $\begin{array}{c}\text { RNA splicing, nad1 intron } 4 \text {, nad } 2 \text { intron } \\
\text { 1, and nad4 intron } 1\end{array}$ & {$[76]$} \\
\hline & Mitochondrion & emp & EMP9 & PLS & RNA editing, $c c m B-43$ and rps4-335 & [77] \\
\hline & Mitochondrion & emp & EMP10 & $\mathrm{P}$ & RNA splicing, nad2 intron 1 & [78] \\
\hline & Mitochondrion & emp & EMP11 & $\mathrm{P}$ & RNA splicing, nad 1 intron $1,2,3$, and 4 & [79] \\
\hline
\end{tabular}


Table 1. Cont.

\begin{tabular}{|c|c|c|c|c|c|c|}
\hline Species & $\begin{array}{l}\text { Subcellular } \\
\text { Localization }\end{array}$ & $\begin{array}{c}\text { Mutant } \\
\text { Phenotype }\end{array}$ & $\begin{array}{l}\text { Protein } \\
\text { Name }\end{array}$ & $\begin{array}{l}\text { PPR } \\
\text { Class }\end{array}$ & Function(s) & References \\
\hline & Mitochondrion & emp & EMP12 & $\mathrm{P}$ & RNA splicing, nad2 intron 1,2 , and 4 & [80] \\
\hline & Chloroplast & $s m k$ & qKW9 & PLS & RNA editing, NdhB-246 & [81] \\
\hline & Mitochondrion & emp & EMP16 & $\mathrm{P}$ & RNA splicing, nad2 intron 4 & [82] \\
\hline & Mitochondrion & emp & EMP17 & PLS & RNA editing, $\mathrm{ccmF}_{C^{-}}-799$ and nad2-677 & [83] \\
\hline & Mitochondrion & emp & EMP18 & PLS & RNA editing, atp6-635 and cox2-449 & [84] \\
\hline & Mitochondrion & emp & EMP21 & PLS & RNA editing, multiple sites & [85] \\
\hline & Mitochondrion & emp & EMP32 & $\mathrm{P}$ & RNA splicing, nad7 intron 2 & [86] \\
\hline & Mitochondrion & emp & EMP602 & $\mathrm{P}$ & RNA splicing, nad4 intron 1 and 3 & [87] \\
\hline & Mitochondrion & emp & EMP603 & $\mathrm{P}$ & RNA splicing, nad1 intron 2 & [88] \\
\hline & Mitochondrion & emp & PPR14 & $\mathrm{P}$ & $\begin{array}{l}\text { RNA splicing, nad } 2 \text { intron } 3, \text { nad7 intron } \\
1 \text { and } 2\end{array}$ & [89] \\
\hline & Mitochondrion & emp & PPR18 & $\mathrm{P}$ & RNA splicing, nad4 intron 1 & [90] \\
\hline & Mitochondrion & emp & PPR27 & PLS & RNA editing, multiple sites & [91] \\
\hline & Mitochondrion & emp & PPR101 & $\mathrm{P}$ & RNA splicing, nad5 intron 1 and 2 & [92] \\
\hline & Mitochondrion & emp & PPR231 & $\mathrm{P}$ & $\begin{array}{l}\text { RNA splicing, nad5 intron 1, 2, } 3 \text { and } \\
\text { nad } 2 \text { intron } 3\end{array}$ & [92] \\
\hline & Mitochondrion & emp & PPR-SMR1 & $\mathrm{P}$ & RNA splicing, multiple introns & [93] \\
\hline & Chloroplast & $e m b$ & PPR8522 & $\mathrm{P}$ & $\begin{array}{l}\text { RNA transcription, nearly all } \\
\text { chloroplast-encoded genes }\end{array}$ & {$[94]$} \\
\hline & Chloroplast & $e m b$ & EMB-7L & $\mathrm{P}$ & RNA splicing, multiple introns & [95] \\
\hline \multirow{10}{*}{ Arabidopsis } & Mitochondrion & dek & OTP43 & $\mathrm{P}$ & RNA splicing, nad1 intron 1 & [96] \\
\hline & Mitochondrion & $s m k$ & PPR19 & $\mathrm{P}$ & RNA stabilization, nad1 mature mRNA & [97] \\
\hline & Mitochondrion & emp & BLX & PLS & $\begin{array}{l}\text { RNA editing, multiple sites; RNA } \\
\text { splicing, nad } 1 \text { intron } 4 \text { and nad } 2 \text { intron } 1\end{array}$ & [98] \\
\hline & Chloroplast & $e m b$ & AtPPR2 & $\mathrm{P}$ & RNA translation & [99] \\
\hline & Chloroplast & $e m b$ & ECD2 & $\mathrm{P}$ & $\begin{array}{l}\text { RNA splicing, } n d h A, y c f 3 \text { intron } 1, r p s 12 \\
\text { intron } 2 \text { and } c l p p \text { intron } 2\end{array}$ & {$[100]$} \\
\hline & Chloroplast & $e m b$ & EMB2654 & $\mathrm{P}$ & RNA splicing, rps12 intron 1 & [101] \\
\hline & Mitochondrion & $e m b$ & EMB2794 & $\mathrm{P}$ & RNA splicing, nad2 intron 2 & [102] \\
\hline & Nucleus & $e m b$ & GRP23 & $\mathrm{P}$ & RNA transcription & {$[103]$} \\
\hline & Mitochondrion & emb & MID1 & $\mathrm{P}$ & RNA splicing, nad2 intron 1 & [104] \\
\hline & Chloroplast & $e m b$ & PMD3 & $\mathrm{P}$ & RNA splicing, $\operatorname{trn} A, n d h B$, and $c l p P-1$ & [105] \\
\hline
\end{tabular}

Most PPR proteins identified to date are targeted to mitochondria and/or chloroplasts [4]. The disruption of PPR proteins localized to chloroplasts usually results in the emb mutants that are defective in embryogenesis, but relatively normal in endosperm development. For instance, PPR8522 [94] and EMB-7L [95] in maize and GRP23 [103] in Arabidopsis are necessary for embryogenesis, and their mutations lead to arrested embryo development at the transition stage, resulting in an embryo-lethal phenotype. For mitochondrion-targeted PPR proteins, their disruptions mostly cause diverse seed development mutants, including smk, dek, and emp, with different degrees of defects in embryo and endosperm. The loss-of-function of SMK1 [65], SMK4 [66], SMK6 [67], ZmSMK9 [68], PPR2263 [69], and MPPR6 [70] in maize and PPR19 [97] in Arabidopsis arrests both embryo and endosperm development, resulting in smk phenotypes. Some characterized mitochondrion-targeted PPR proteins, such as DEK2 [52], DEK10 [53], DEK35 [54], DEK36 [55], DEK37 [56], DEK39 [57], DEK40 [58], DEK41/43 [59,60], DEK46 [61], and DEK53 [62] in maize, are necessary for seed development, and their disruptions result in dek mutants with arrested development of both the embryo and endosperm at an early stage. Meanwhile, many PPR proteins are targeted to mitochondria and function in development of both embryo and endosperm, and mutations in their encoding genes arrest embryo and endosperm development at early stages and even result in embryo lethality. For example, Emp5 encodes a mitochondrion-targeted DYW-type PPR protein, the emp5 mutants exhibit abortion of embryo and endosperm development at early stages in maize [74]. Loss-of-function of the mitochondrial P-type PPR protein EMP10 severely disturbs embryo and endosperm development, resulting in empty pericarp or papery seeds in maize [78]. Additionally, the P-type protein PPR5 was recently identified as a regulator required for endosperm development in rice, the ppr5 mutants develop small starch grains [106].

\section{Mechanisms of PPR Protein-Mediated RNA Processing in Plant Organelles}

Mostly, above-mentioned functions of PPR proteins in plant growth, development and stress responses are caused by the disturbed organellar gene expression pattern [107]. As a large family of RNA-binding proteins, some PPR proteins have shown to be required 
for post-transcriptional RNA processing events in plant mitochondria and chloroplasts [4]. These observations lead to an increasing interest towards understanding the nature and details of PPR protein-mediated RNA processing, and some progress has been made in the last decade [108], in particular, the mechanisms of PPR proteins involved in C-to-U RNA editing and in group II intron splicing.

\subsection{Molecular Mechanisms of PPR Proteins in C-to-U RNA Editing}

C-to-U RNA editing is highly prevalent in plant organelles, which converts cytidines to uridines at specific sites in transcripts of chloroplasts and plant mitochondria. The chemical nature of C-to-U RNA editing is through a site-specific cytidine deamination reaction [109]. To date, many E/E+ or DYW-subclass PPR proteins have been characterized as C-to-U RNA editing factors for one, several or multiple editing sites in plant organelles $[84,85]$. The DYW domain of some PPR proteins contains a conserved zinc-binding motif $\left(\mathrm{HxE}(\mathrm{x})_{\mathrm{n}} \mathrm{CxxC}\right)$ in common with cytidine deaminase [110], and thus it has been proposed as the best candidate to catalyze deamination. Experimental support for this hypothesis came from mutagenesis experiments that modified the deaminase signature sequence. Mutation of several residues in cytidine deaminase signature of DYW1 significantly decreases the zinc-binding capacity and abolishes the editing of $n d h D-1$ [111]. The glutamate residue is required for the cytidine deaminase-catalyzed reactions. Mutagenesis of glutamate residue in the zinc-binding motif of OTP84 and CREF7 leads to loss of their editing activity at their cognate editing sites [112]. Recently, the DYW-PPR proteins called PPR56 and PPR65 from Physcomitrella patens were shown to drive C-to-U RNA editing individually at their corresponding targets in E. coli [113], and the purified recombinant PPR65 was found to exhibit the function of editing at its target site in synthetic RNAs [114], indicating a single DYW-deaminase domain-containing PPR protein is sufficient for editing its defined RNA targets within the bacterial cells and in vitro. In 2021, Takenaka et al. analyzed the structures of a DYW domain, they found that it contains a cytidine deaminase domain and a characteristic DYW motif, with catalytic and structural zinc atoms, respectively. Moreover, the DYW motif is stabilized by a zinc atom and functions in the control of zinc-mediated catalysis by altering the coordination setting around the catalytic zinc atom [115]. These results reinforce the hypothesis that the DYW domain functions as cytidine deaminase that carries out C-to-U RNA editing in plant organelles.

$\mathrm{E}$ and E+-type PPR proteins lack the DYW domain that contributes to the catalytic reaction of C-to-U RNA editing, and their exact function in the RNA-editing process remains unclear. Some studies rather suggest that they can form protein complexes with a DYW-type protein for a complete editing event. The first of these PPR editing factors to be identified is an E-type PPR protein CRR2. To edit chloroplast $n d h D-2$ site, CRR2 physically interacts with DYW1 that carries very few PPR motifs, no canonical E and E+ domains but end with a DYW domain [116]. Where, in which CRR2 acts as an editing site recognition factor, while DYW1 has key features of an editing deaminase [111]. DYW2 is a DYW-type PPR protein recently shown to be required for the editing of more than 100 sites in mitochondria and chloroplasts [117], and almost all of the DYW2 dependent editing sites are targets of E+-type PPR proteins, such as PGN, MEF37, OTP90 [118], etc. The functional association and physical interactions of DYW2 and E+-type PPR proteins suggest that DYW2 complements missing DYW domains in E+-type PPR proteins [117-119].

C-to-U RNA editing in plant organelles is performed by an editosome composed of RNA and protein factors. In addition to PPR proteins, several other protein factors were shown to be part of RNA editosome, and some of these protein factors were found to physically interact with each other or with PPR proteins. Previous studies indicate that the multiple organellar RNA editing factors (MORFs) can interact with the PLS-class PPR proteins and participate in RNA editing. MORF8 interacts with the DYW-type proteins RARE1 and MEF10 to participate in the C-to-U RNA editing in Arabidopsis chloroplast $a c c D$ and mitochondrial nad2 transcripts, respectively [120,121]. ZmMORF8 interacts with DYWtype proteins EMP5 and EMP21, and are together required for editing at multiple sites in 
maize mitochondria [85]. In addition, other MORF proteins have been shown to be involved in C-to-U RNA editing in plant mitochondria or chloroplasts, and physically interact with PLS-class PPR proteins [91,122]. RNA binding activity has been reported for PPR proteins, and a PPR-RNA recognition code has been elucidated and experimentally validated [123] The PLS-class PPR proteins recognize and bind to RNA sequences upstream of the edited cytidine residues, whereas the MORF proteins mediate their RNA-binding activity [124]. For instance, MORF9 binding induced significant compressed conformational changes of PLS-class PPR protein, leading to the increase in the RNA-binding activity of PPR proteins [125].

These data indicate that PPR proteins serve as the primary recognition factors that single out specific cytidines to be converted into uridines in organellar transcripts of higher plants. These data also highlight that the DYW domain is the likely cytidine deaminase performing the cytidine deamination reaction (Figure 2A).

A

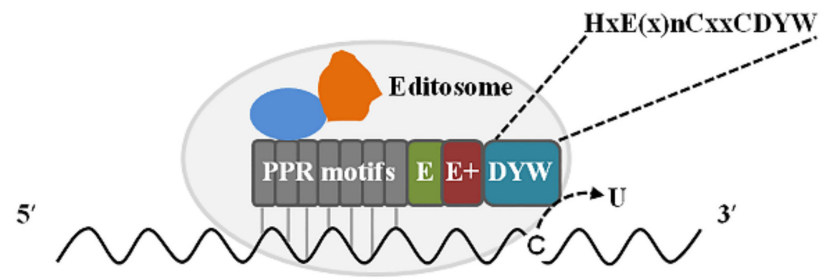

B

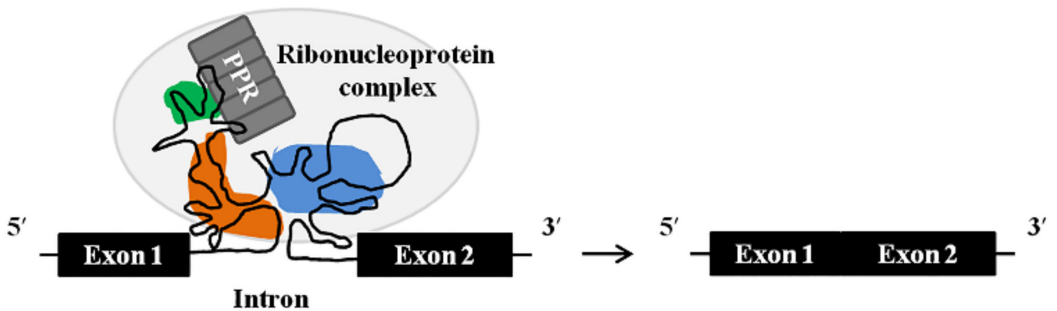

Figure 2. Proposed model for the molecular mechanisms of PPR proteins in plant organellar RNA editing and RNA splicing. (A) A model for the involvement of a DYW-type PPR protein in C-to-U RNA editing. C-to-U RNA editing in plant mitochondria and chloroplasts is carried out by an editosome composed of proteins and RNA. PPR motifs bind to its target RNA according to the PPR-RNA recognition code [123], which can be influenced by other proteins (shown in blue and orange). The DYW domain containing a cytidine deaminase signature (listed as $\mathrm{HxE}(\mathrm{x}) \mathrm{nCxxC})$ converts the target cytidine $(C)$ to uridine $(\mathrm{U})$. (B) A model for the involvement of a P-class PPR protein in intron splicing. The splicing of introns in plant mitochondria and chloroplasts is proposed to be mediated by a ribonucleoprotein complex, where PPR proteins and other RNA-binding proteins (shown in green, blue, and orange) bind to their target intron to help its folding and stabilizing in an active form.

\subsection{Molecular Mechanisms of PPR Proteins in Group II Intron Splicing}

Group II introns commonly exist in organellar genomes of land plants, with more than 20 in the mitochondrial and chloroplast genomes of Arabidopsis, rice, and maize. Because of the loss of the ability to undergo self-splicing, the splicing of organellar group II introns in higher plants relies on various protein cofactors coming from different families and encoded by nuclear and organellar genomes $[126,127]$. So far, some P-class PPR proteins have been shown to be required for the splicing of plant mitochondrial and chloroplast introns [4], such as ABO5, MTL1, TANG2, OTP439, OTP43, and SLO3 in Arabidopsis [33,96,128-130], DEK2, DEK35, DEK37, EMP8, EMP10, EMP16, PPR14, EMP24, EMP25, and PPR-SMR1 in maize $[52,54,56,76,78,82,89,93,131]$, as well as OsNPPR1, OsNPPR3, FLO10, and PPR5 in rice $[106,132-134]$. These PPR proteins are involved in the splicing of one, several or multiple introns in plant mitochondria or chloroplasts. For example, DEK37 [56] in maize, MID1 [104] in Arabidopsis, and FLO10 [133] in rice are specifically involved in the splicing of a single intron in mitochondria or chloroplasts. EMP8 [76] and PPR14 [89] participate in 
the splicing of several mitochondrial introns in maize, while PPR-SMR1 in maize is required for the splicing of nearly $75 \%$ of the mitochondrial introns [93]. Besides, some PLS-class PPR proteins that are usually characterized to function in RNA editing, are also implicated in RNA splicing. SLO4 was reported to affect nad2 intron 1 splicing in Arabidopsis [135]. PpPPR43 influences the splicing efficiency of cox1 intron 3 in Physcomitrella patens [136].

Although some PPR proteins acted as splicing cofactors in plant organelles have been identified, how these PPR proteins function in the splicing of plant organellar group II introns is not well understood. The recruitment of PPR proteins and other splicing factors is generally required for the splicing of a group II intron in plant organelles. In chloroplasts, the PPR proteins PPR4 and EMB2654 [101,137,138], the CRM (chloroplast RNA splicing and ribosome maturation) protein CAF2 [139], the PTH (peptidyl-tRNA hydrolase) protein CRS2 [140], and the DEAD-box RNA helicase protein RH3 [141] are required for the removal of intron 1 from $r p s 12$ pre-mRNA, and they are all found in a large ribonucleoprotein complex. Similarly, in mitochondria, three PPR proteins, MISF68 [142], ZmSMK9 [68], and PPR-SMR1 [93], and a ribosomal protein uL18-L1 [143] participate in the splicing of nad5 intron 1. In addition, the PPR protein PPR14 was reported to physically interact with a PPR protein PPR-SMR1 and a CRM-domain protein Zm-mCSF1, and they are required for the splicing of mitochondrial nad2 intron 3 in maize [89,93]. As members of RNA-binding protein families, several P-class PPR proteins have been found to bind to their dependent splicing introns. For example, the chloroplast-localized THA8 is required for the splicing of $y c f 3$ intron 2 and trnA intron in maize [144], and its orthologues from Brachypodium distachyon can bind to ycf 3 intron 2 in vitro through multiple purine-rich sequences distributed in intron [145]. PPR4 and EMB2654 are known to be involved in the splicing of the chloroplast $r p s 12$ intron 1 in maize and Arabidopsis, respectively [101,146]. RNA footprinting and EMSA experiments indicated that the Arabidopsis ortholog of PPR4 binds to a sequence near the $5^{\prime}$ end of rps12 intron 1, while EMB2654 binds to a sequence near the $3^{\prime}$ end of rps12 intron $1[101,146]$. By associating with their target intron, these PPR proteins and other splicing factors could form ribonucleoprotein complexes that help intron folding and stabilize their structure in an active form [146,147].

Taken together, these findings strongly suggest that PPR proteins participate in the splicing of group II intron in plant organelles might by binding to a specific RNA sequence in their target intron and interacting with other splicing factors to form a large complex that is required for the splicing performed (Figure 2B), but how these proteins collaborate or whether they act independently remains to be elucidated.

\section{Conclusions and Perspectives}

Although there is more evidence indicating that PPR proteins specifically take part in multiple aspects of RNA processing in plant organelles [4], only a few PPR proteins have been functionally characterized in contrast to the vast majority of PPR members. Moreover, computational and structural studies have provided new insights into RNA recognition and cytidine deamination reaction by PPR proteins in C-to-U RNA editing events $[115,123,148]$. However, little is known about the mechanistic details of PPR proteins involved in other RNA processing events. Therefore, there is a need to promote a more comprehensive understanding of PPR proteins. Firstly, why are PPR proteins particularly prevalent in land plants, and display diverse functions in organellar RNA processing? Secondly, how do PPR proteins interact with each other or other proteins to achieve their final functionality, and how do these interactions contribute to PPR activities in organellar RNA processing? Finally, what roles do PPR proteins play in the regulatory network of nuclear-cytoplasmic interaction in land plants? Maybe plenty of evolutionary analyses will provide deeper insight into their subtle classification and distribution. Functional identification of other PPR proteins and further analysis of co-expressed PPR genes will reveal whether they also play roles in organellar RNA processing or whether they are involved in other steps of RNA expression in plant organelles, and will allow us to define the regulatory network of nuclear-cytoplasmic interaction in land plants. Experimental 
identification of RNA targets of PPR proteins and crystal structure analyses of protein-RNA complexes are however necessary to elucidate the action mode of PPR proteins in detail. Besides, more attention should be paid to PPR interacting proteins that could directly affect the PPR protein effects, such as MORF proteins [47]. These studies will help to better clarify the mechanisms of PPR proteins, and also help to understand the details of plant organellar RNA processing.

Author Contributions: X.L. and Y.J. designed the outlines in this review and edited the manuscript. X.L. wrote the original manuscript. M.S., S.L. (Shijuan Liu), Q.T. and S.L. (Shihui Li) participated in the collection and collation of literatures. All authors have read and agreed to the published version of the manuscript.

Funding: This work was supported by the National Natural Science Foundation of China (32070246), Qufu Normal University Doctoral Fund Project (BSQD20152493), and Shandong Province Higher Educational Science and Technology Program (J16LE09).

Conflicts of Interest: The authors declare that there are no conflicts of interest.

\section{References}

1. Small, I.D.; Peeters, N. The PPR motif-a TPR-related motif prevalent in plant organellar proteins. Trends Biochem. Sci. 2000, 25, 45-47. [CrossRef]

2. Lurin, C.; Andrés, C.; Aubourg, S.; Bellaoui, M.; Bitton, F.; Bruyère, C.; Caboche, M.; Debast, C.; Gualberto, J.; Hoffmann, B.; et al. Genome-wide analysis of Arabidopsis pentatricopeptide repeat proteins reveals their essential role in organelle biogenesis. Plant Cell 2004, 16, 2089-2103. [CrossRef] [PubMed]

3. Cheng, S.F.; Gutmann, B.; Zhong, X.; Ye, Y.T.; Fisher, M.F.; Bai, F.Q.; Castleden, I.; Song, Y.; Song, B.; Huang, J.Y.; et al. Redefining the structural motifs that determine RNA binding and RNA editing by pentatricopeptide repeat proteins in land plants. Plant $J$. 2016, 85, 532-547. [CrossRef] [PubMed]

4. Barkan, A.; Small, I. Pentatricopeptide repeat proteins in plants. Annu. Rev. Plant Biol. 2014, 65, 415-442. [CrossRef] [PubMed]

5. Schmitz-Linneweber, C.; Small, I. Pentatricopeptide repeat proteins: A socket set for organelle gene expression. Trends Plant Sci. 2008, 13, 663-670. [CrossRef]

6. Chase, C.D. Cytoplasmic male sterility: A window to the world of plant mitochondrial-nuclear interactions. Trends Genet. 2007, 23, 81-90. [CrossRef]

7. Bohra, A.; Jha, U.C.; Adhimoolam, P.; Bisht, D.; Singh, N.P. Cytoplasmic male sterility (CMS) in hybrid breeding in field crops. Plant Cell Rep. 2016, 35, 967-993. [CrossRef]

8. Linke, B.; Börner, T. Mitochondrial effects on flower and pollen development. Mitochondrion 2005, 5, 389-402. [CrossRef] [PubMed]

9. Eckardt, N.A. Cytoplasmic male sterility and fertility restoration. Plant Cell 2006, 18, 515-517. [CrossRef]

10. Wang, Z.H.; Zou, Y.J.; Li, X.Y.; Zhang, Q.Y.; Chen, L.T.; Wu, H.; Su, D.H.; Chen, Y.L.; Guo, J.X.; Luo, D.; et al. Cytoplasmic male sterility of rice with Boro II cytoplasm is caused by a cytotoxic peptide and is restored by two related PPR motif genes via distinct modes of mRNA silencing. Plant Cell 2006, 18, 676-687. [CrossRef] [PubMed]

11. Kazama, T.; Nakamura, T.; Watanabe, M.; Sugita, M.; Toriyama, K. Suppression mechanism of mitochondrial ORF79 accumulation by Rf1 protein in BT-type cytoplasmic male sterile rice. Plant J. 2008, 55, 619-628. [CrossRef]

12. Luo, D.P.; Xu, H.; Liu, Z.L.; Guo, J.X.; Li, H.Y.; Chen, L.T.; Fang, C.; Zhang, Q.Y.; Bai, M.; Yao, N.; et al. A detrimental mitochondrial-nuclear interaction causes cytoplasmic male sterility in rice. Nat. Genet. 2013, 45, 573-577. [CrossRef] [PubMed]

13. Tang, H.; Luo, D.; Zhou, D.; Zhang, Q.; Tian, D.; Zheng, X.; Chen, L.; Liu, Y.G. The rice restorer Rf4 for wild-abortive cytoplasmic male sterility encodes a mitochondrial-localized PPR protein that functions in reduction of WA352 transcripts. Mol. Plant 2014, 7, 1497-1500. [CrossRef] [PubMed]

14. Hu, J.; Wang, K.; Huang, W.C.; Liu, G.; Gao, Y.; Wang, J.M.; Huang, Q.; Ji, Y.X.; Qin, X.J.; Wan, L.; et al. The rice pentatricopeptide repeat protein RF5 restores fertility in Hong-Lian cytoplasmic male-sterile lines via a complex with the glycine-rich protein GRP162. Plant Cell 2012, 24, 109-122. [CrossRef]

15. Huang, W.C.; Yu, C.C.; Hu, J.; Wang, L.L.; Dan, Z.W.; Zhou, W.; He, C.L.; Zeng, Y.F.; Yao, G.X.; Qi, J.Z.; et al. Pentatricopeptiderepeat family protein RF6 functions with hexokinase 6 to rescue rice cytoplasmic male sterility. Proc. Natl. Acad. Sci. USA 2015, 112, 14984-14989. [CrossRef]

16. Brown, G.G.; Formanová, N.; Jin, H.; Wargachuk, R.; Dendy, C.; Patil, P.; Laforest, M.; Zhang, J.F.; Cheung, W.Y.; Landry, B.S. The radish $R f o$ restorer gene of Ogura cytoplasmic male sterility encodes a protein with multiple pentatricopeptide repeats. Plant $J$. 2003, 35, 262-272. [CrossRef]

17. Uyttewaal, M.; Arnal, N.; Quadrado, M.; Martin-Canadell, A.; Vrielynck, N.; Hiard, S.; Gherbi, H.; Bendahmane, A.; Budar, F.; Mireau, H. Characterization of Raphanus sativus pentatricopeptide repeat proteins encoded by the fertility restorer locus for Ogura cytoplasmic male sterility. Plant Cell 2008, 20, 3331-3345. [CrossRef] [PubMed] 
18. Wang, Z.W.; De Wang, C.D.; Mei, S.Y.; Gao, L.; Zhou, Y.; Wang, T. An insertion-deletion at a pentatricopeptide repeat locus linked to fertility transition to cytoplasmic male sterility in radish (Raphanus sativus L.). Mol. Breed. 2015, 35, 108-112. [CrossRef]

19. Imai, R.; Koizuka, N.; Fujimoto, H.; Hayakawa, T.; Sakai, T.; Imamura, J. Delimitation of the fertility restorer locus $R f k 1$ to a $43-k b$ contig in Kosena radish (Raphanus sativus L.). Mol. Genet. Genom. 2003, 269, 388-394. [CrossRef]

20. Klein, R.R.; Klein, P.E.; Mullet, J.E.; Minx, P.; Rooney, W.L.; Schertz, K.F. Fertility restorer locus Rf1 of sorghum (Sorghum bicolor L.) encodes a pentatricopeptide repeat protein not present in the colinear region of rice chromosome 12. Theor. Appl. Genet. 2005, 111, 994-1012. [CrossRef]

21. Madugula, P.; Uttam, A.G.; Tonapi, V.A.; Ragimasalawada, M. Fine mapping of Rf2, a major locus controlling pollen fertility restoration in sorghum $\mathrm{A}_{1}$ cytoplasm, encodes a PPR gene and its validation through expression analysis. Plant Breed. 2018, 137, 148-161. [CrossRef]

22. Liu, Z.; Yang, Z.; Wang, X.; Li, K.; An, H.; Liu, J.; Yang, G.S.; Fu, T.; Yi, B.; Hong, D.F. A mitochondria-targeted PPR protein restores pol cytoplasmic male sterility by reducing orf224 transcript levels in oilseed rape. Mol. Plant 2016, 9, 1082-1084. [CrossRef] [PubMed]

23. Liu, Z.; Dong, F.M.; Wang, X.; Wang, T.; Su, R.; Hong, D.F.; Yang, G.S. A pentatricopeptide repeat protein restores nap cytoplasmic male sterility in Brassica napus. J. Exp. Bot. 2017, 68, 4115-4123. [CrossRef] [PubMed]

24. Gillman, J.D.; Bentolila, S.; Hanson, M.R. The petunia restorer of fertility protein is part of a large mitochondrial complex that interacts with transcripts of the CMS-associated locus. Plant J. 2007, 49, 217-227. [CrossRef]

25. Zhang, H.M.; Wu, J.Q.; Dai, Z.H.; Qin, M.L.; Hao, L.Y.; Ren, Y.J.; Li, Q.F.; Zhang, L.G. Allelism analysis of BrRfp locus in different restorer lines and map-based cloning of a fertility restorer gene, BrRfp1, for pol CMS in Chinese cabbage (Brassica rapa L.). Theor. Appl. Genet. 2017, 130, 539-547. [CrossRef]

26. Rizzolatti, C.; Bury, P.; Tatara, E.; Pin, P.A.; Rodde, N.; Bergès, H.; Budar, F.; Mireau, H.; Gielen, J.J.L. Map-based cloning of the fertility restoration locus $R f m 1$ in cultivated barley (Hordeum vulgare). Euphytica 2017, 213, 276-287. [CrossRef]

27. Chen, L.T.; Liu, Y.G. Male sterility and fertility restoration in crops. Annu. Rev. Plant Biol. 2014, 65, 579-606. [CrossRef]

28. Jiang, S.C.; Mei, C.; Liang, S.; Yu, Y.T.; Lu, K.; Wu, Z.; Wang, X.F.; Zhang, D.P. Crucial roles of the pentatricopeptide repeat protein SOAR1 in Arabidopsis response to drought, salt and cold stresses. Plant Mol. Biol. 2015, 88, 369-385. [CrossRef]

29. Wu, G.Z.; Chalvin, C.; Hoelscher, M.; Meyer, E.H.; Wu, X.N.; Bock, R. Control of retrograde signaling by rapid turnover of GENOMES UNCOUPLED1. Plant Physiol. 2018, 176, 2472-2495. [CrossRef]

30. Mochizuki, N.; Susek, R.; Chory, J. An intracellular signal transduction pathway between the chloroplast and nucleus is involved in de-etiolation. Plant Physiol. 1996, 112, 1465-1469. [CrossRef]

31. Kobayashi, K.; Suzuki, M.; Tang, J.W.; Nagata, N.; Ohyama, K.; Seki, H.; Kiuchi, R.; Kaneko, Y.; Nakazawa, M.; Matsui, M.; et al. LOVASTATIN INSENSITIVE 1, a novel pentatricopeptide repeat protein, is a potential regulatory factor of isoprenoid biosynthesis in Arabidopsis. Plant Cell Physiol. 2007, 48, 322-331. [CrossRef] [PubMed]

32. Zsigmond, L.; Rigoó, G.; Szarka, A.; Szeékely, G.; Ötvös, K.; Darula, Z.; Medzihradszky, K.F.; Koncz, C.; Koncz, Z.; Szabados, L. Arabidopsis PPR40 connects abiotic stress responses to mitochondrial electron transport. Plant Physiol. 2008, 146, 1721-1737. [CrossRef] [PubMed]

33. Liu, Y.; He, J.N.; Chen, Z.Z.; Ren, X.Z.; Hong, X.H.; Gong, Z.Z. ABA overly-sensitive 5 (ABO5), encoding a pentatricopeptide repeat protein required for cis-splicing of mitochondrial nad2 intron 3, is involved in the abscisic acid response in Arabidopsis. Plant $J$. 2010, 63, 749-765. [CrossRef]

34. Laluk, K.; AbuQamar, S.; Mengiste, T. The Arabidopsis mitochondria-localized pentatricopeptide repeat protein PGN functions in defense against necrotrophic fungi and abiotic stress tolerance. Plant Physiol. 2011, 156, 2053-2068. [CrossRef] [PubMed]

35. Murayama, M.; Hayashi, S.; Nishimura, N.; Ishide, M.; Kobayashi, K.; Yagi, Y.; Asami, T.; Nakamura, T.; Shinozaki, K.; Hirayama, T. Isolation of Arabidopsis ahg11, a weak ABA hypersensitive mutant defective in nad4 RNA editing. J. Exp. Bot. 2012, 63, 5301-5310. [CrossRef] [PubMed]

36. Yuan, H.; Liu, D. Functional disruption of the pentatricopeptide protein SLG1 affects mitochondrial RNA editing, plant development, and responses to abiotic stresses in Arabidopsis. Plant J. 2012, 70, 432-444. [CrossRef] [PubMed]

37. Zhu, Q.; Dugardeyn, J.; Zhang, C.Y.; Mühlenbock, P.; Eastmond, P.J.; Valcke, R.; De Coninck, B.; Öden, S.; Karampelias, M.; Cammue, B.P.A.; et al. The Arabidopsis thaliana RNA editing factor SLO2, which affects the mitochondrial electron transport chain, participates in multiple stress and hormone responses. Mol. Plant 2014, 7, 290-310. [CrossRef]

38. Liu, J.M.; Zhao, J.Y.; Lu, P.P.; Chen, M.; Guo, C.H.; Xu, Z.S.; Ma, Y.Z. The E-subgroup pentatricopeptide repeat protein family in Arabidopsis thaliana and confirmation of the responsiveness PPR96 to abiotic stresses. Front. Plant Sci. 2016, 7, 1825. [CrossRef] [PubMed]

39. Emami, H.; Kumar, A.; Kempken, F. Transcriptomic analysis of poco1, a mitochondrial pentatricopeptide repeat protein mutant in Arabidopsis thaliana. BMC Plant Biol. 2020, 20, 209. [CrossRef] [PubMed]

40. Gong, X.D.; Su, Q.Q.; Lin, D.Z.; Jiang, Q.; Xu, J.L.; Zhang, J.H.; Teng, S.; Dong, Y.J. The rice OsV4 encoding a novel pentatricopeptide repeat protein is required for chloroplast development during the early leaf stage under cold stress. J. Integr. Plant Biol. 2014, 56, 400-410. [CrossRef]

41. Wu, L.L.; Wu, J.; Liu, Y.X.; Gong, X.D.; Xu, J.L.; Lin, D.Z.; Dong, Y.J. The rice pentatricopeptide repeat gene TCD10 is needed for chloroplast development under cold stress. Rice 2016, 9, 67-79. [CrossRef] [PubMed] 
42. Tan, J.J.; Tan, Z.H.; Wu, F.Q.; Sheng, P.K.; Heng, Y.Q.; Wang, X.H.; Ren, Y.L.; Wang, J.L.; Guo, X.P.; Zhang, X.; et al. A novel chloroplast-localized pentatricopeptide repeat protein involved in splicing affects chloroplast development and abiotic stress response in rice. Mol. Plant 2014, 7, 1329-1349. [CrossRef] [PubMed]

43. Qiu, T.C.; Zhao, X.S.; Feng, H.J.; Qi, L.L.; Yang, J.; Peng, Y.L.; Zhao, W.S. OsNBL3, a mitochondrion-localized pentatricopeptide repeat protein, is involved in splicing nad5 intron 4 and its disruption causes lesion mimic phenotype with enhanced resistance to biotic and abiotic stresses. Plant Biotechnol. J. 2021. [CrossRef] [PubMed]

44. Tadini, L.; Pesaresi, P.; Kleine, T.; Rossi, F.; Guljamow, A.; Sommer, F.; Mühlhaus, T.; Schroda, M.; Masiero, S.; Pribil, M.; et al. GUN1 controls accumulation of the plastid ribosomal protein S1 at the protein level and interacts with proteins involved in plastid protein homeostasis. Plant Physiol. 2016, 170, 1817-1830. [CrossRef]

45. Takenaka, M.; Zehrmann, A.; Verbitskiy, D.; Kugelmann, M.; Hartel, B.; Brennicke, A. Multiple organellar RNA editing factor (MORF) family proteins are required for RNA editing in mitochondria and plastids of plants. Proc. Natl. Acad. Sci. USA 2012, 109, 5104-5109. [CrossRef]

46. Tadini, L.; Peracchio, C.; Trotta, A.; Colombo, M.; Mancini, I.; Jeran, N.; Costa, A.; Faoro, F.; Marsoni, M.; Vannini, C.; et al. GUN1 influences the accumulation of NEP-dependent transcripts and chloroplast protein import in Arabidopsis cotyledons upon perturbation of chloroplast protein homeostasis. Plant J. 2020, 101, 1198-1220. [CrossRef]

47. Zhao, X.B.; Huang, J.Y.; Chory, J. GUN1 interacts with MORF2 to regulate plastid RNA editing during retrograde signaling. Proc. Natl. Acad. Sci. USA 2019, 116, 10162-10167. [CrossRef]

48. Verbitskiy, D.; Zehrmann, A.; van der Merwe, J.A.; Brennicke, A.; Takenaka, M. The PPR protein encoded by the LOVASTATIN INSENSITIVE1 gene is involved in RNA editing at three sites in mitochondria of Arabidopsis thaliana. Plant J. 2010, 61, 446-455. [CrossRef]

49. Goldberg, R.B.; de Paiva, G.; Yadegari, R. Plant embryogenesis: Zygote to seed. Science 1994, 266, 605-614. [CrossRef]

50. Linkies, A.; Graeber, K.; Knight, C.; Leubner-Metzger, G. The evolution of seeds. New Phytol. 2010, 186, 817-831. [CrossRef]

51. Dai, D.W.; Ma, Z.Y.; Song, R.T. Maize kernel development. Mol. Breed. 2021, 41, 2. [CrossRef]

52. Qi, W.W.; Yang, Y.; Feng, X.Z.; Zhang, M.L.; Song, R.T. Mitochondrial function and maize kernel development requires Dek2, a pentatricopeptide repeat protein involved in nad1 mRNA splicing. Genetics 2017, 205, 239-249. [CrossRef]

53. Qi, W.W.; Tian, Z.R.; Lu, L.; Chen, X.Z.; Chen, X.Z.; Zhang, W.; Song, R. Editing of mitochondrial transcripts nad3 and cox2 by Dek10 is essential for mitochondrial function and maize plant development. Genetics 2017, 205, 1489-1501. [CrossRef]

54. Chen, X.Z.; Feng, F.; Qi, W.W.; Xu, L.M.; Yao, D.S.; Wang, Q.; Song, R.T. Dek35 encodes a PPR protein that affects cis-splicing of mitochondrial nad4 intron 1 and seed development in maize. Mol. Plant 2017, 10, 427-441. [CrossRef] [PubMed]

55. Wang, G.; Zhong, M.Y.; Shuai, B.L.; Song, J.D.; Zhang, J.; Han, L.; Ling, H.L.; Tang, Y.P.; Wang, G.F.; Song, R.T. E+ subgroup PPR protein defective kernel 36 is required for multiple mitochondrial transcripts editing and seed development in maize and Arabidopsis. New Phytol. 2017, 214, 1563-1578. [CrossRef]

56. Dai, D.W.; Luan, S.C.; Chen, X.Z.; Wang, Q.; Feng, Y.; Zhu, C.G.; Qi, W.W.; Song, R.T. Maize Dek37 encodes a P-type PPR protein that affects cis-splicing of mitochondrial nad2 intron 1 and seed development. Genetics 2018, 208, 1069-1082. [CrossRef] [PubMed]

57. Li, X.J.; Gu, W.; Sun, S.L.; Chen, Z.L.; Chen, J.; Song, W.B.; Zhao, H.M.; Lai, J.S. Defective Kernel 39 encodes a PPR protein required for seed development in maize. J. Integr. Plant Biol. 2018, 60, 45-64. [CrossRef]

58. Ren, R.C.; Lu, X.D.; Zhao, Y.J.; Wei, Y.M.; Wang, L.L.; Zhang, L.; Zhang, W.T.; Zhang, C.Y.; Zhang, X.S.; Zhao, X.Y. Pentatricopeptide repeat protein DEK40 is required for mitochondrial function and kernel development in maize. J. Exp. Bot. 2019, 70, 6163-6179. [CrossRef]

59. Ren, R.C.; Wang, L.L.; Zhang, L.; Zhao, Y.J.; Wu, J.W.; Wei, Y.M.; Zhang, X.S.; Zhao, X.Y. DEK43 is a P-type pentatricopeptide repeat (PPR) protein responsible for the cis-splicing of nad4 in maize mitochondria. J. Integr. Plant Biol. 2020, 62, 299-313. [CrossRef] [PubMed]

60. Zhu, C.G.; Jin, G.P.; Fang, P.; Zhang, Y.; Feng, X.Z.; Tang, Y.P.; Qi, W.W.; Song, R.T. Maize pentatricopeptide repeat protein DEK41 affects cis-splicing of mitochondrial nad4 intron 3 and is required for normal seed development. J. Exp. Bot. 2019, 70, 3795-3808. [CrossRef]

61. Xu, C.H.; Song, S.; Yang, Y.Z.; Lu, F.; Zhang, M.D.; Sun, F.; Jia, R.X.; Song, R.L.; Tan, B.C. DEK46 performs C-to-U editing of a specific site in mitochondrial nad7 introns that is critical for intron splicing and seed development in maize. Plant J. 2020, 103, 1767-1782. [CrossRef] [PubMed]

62. Dai, D.W.; Jin, L.F.; Huo, Z.Z.; Yan, S.M.; Ma, Z.Y.; Qi, W.W.; Song, R.T. Maize pentatricopeptide repeat protein DEK53 is required for mitochondrial RNA editing at multiple sites and seed development. J. Exp. Bot. 2020, 71, 6246-6261. [CrossRef] [PubMed]

63. Ren, R.C.; Yan, X.W.; Zhao, Y.J.; Wei, Y.M.; Lu, X.D.; Zang, J.; Wu, J.W.; Zheng, G.M.; Ding, X.H.; Zhang, X.S.; et al. The novel E-subgroup pentatricopeptide repeat protein DEK55 is responsible for RNA editing at multiple sites and for the splicing of nad1 and nad4 in maize. BMC Plant Biol. 2020, 20, 553. [CrossRef]

64. Fan, K.J.; Peng, Y.X.; Ren, Z.J.; Li, D.L.; Zhen, S.H.; Hey, S.; Cui, Y.; Fu, J.J.; Gu, R.L.; Wang, J.H.; et al. Maize defective kernel605 encodes a canonical DYW-Type PPR protein that edits a conserved site of nad1 and is essential for seed nutritional quality. Plant Cell Physiol. 2020, 61, 1954-1966. [CrossRef]

65. Li, X.J.; Zhang, Y.F.; Hou, M.M.; Sun, F.; Shen, Y.; Xiu, Z.H.; Wang, X.M.; Chen, Z.L.; Sun, S.S.M.; Small, I.; et al. Small kernel 1 encodes a pentatricopeptide repeat protein required for mitochondrial nad7 transcript editing and seed development in maize (Zea mays) and rice (Oryza sativa). Plant J. 2014, 79, 797-809. [CrossRef] 
66. Wang, H.C.; Sayyed, A.; Liu, X.Y.; Yang, Y.Z.; Sun, F.; Wang, Y.; Wang, M.D.; Tan, B.C. SMALL KERNEL4 is required for mitochondrial cox1 transcript editing and seed development in maize. J. Integr. Plant Biol. 2020, 62, 777-792. [CrossRef]

67. Ding, S.; Liu, X.Y.; Wang, H.C.; Wang, Y.; Tang, J.J.; Yang, Y.Z.; Tan, B.C. SMK6 mediates the C-to-U editing at multiple sites in maize mitochondria. J. Plant Physiol. 2019, 240, 152992. [CrossRef] [PubMed]

68. Pan, Z.Y.; Liu, M.; Xiao, Z.Y.; Ren, X.M.; Zhao, H.L.; Gong, D.M.; Liang, K.; Tan, Z.D.; Shao, Y.Q.; Qiu, F.Z. ZmSMK9, a pentatricopeptide repeat protein, is involved in the cis-splicing of nad5, kernel development and plant architecture in maize. Plant Sci. 2019, 288, 110205. [CrossRef]

69. Sosso, D.; Mbelo, S.; Vernoud, V.; Gendrot, G.; Dedieu, A.; Chambrier, P.; Dauzat, M.; Heurtevin, L.; Guyon, V.; Takenaka, M.; et al. PPR2263, a DYW-subgroup pentatricopeptide repeat protein, is required for mitochondrial nad5 and cob transcript editing, mitochondrion biogenesis, and maize growth. Plant Cell 2012, 24, 676-691. [CrossRef]

70. Manavski, N.; Guyon, V.; Meurer, J.; Wienand, U.; Brettschneider, R. An essential pentatricopeptide repeat protein facilitates $5^{\prime}$ maturation and translation initiation of rps3 mRNA in maize mitochondria. Plant Cell 2012, 24, 3087-3105. [CrossRef]

71. Yang, Y.Z.; Ding, S.; Wang, Y.; Wang, H.C.; Liu, X.Y.; Sun, F.; Xu, C.H.; Liu, B.H.; Tan, B.C. PPR20 is required for the cis-splicing of mitochondrial nad2 intron 3 and seed development in maize. Plant Cell Physiol. 2020, 61, 370-380. [CrossRef] [PubMed]

72. Zhang, Y.F.; Suzuki, M.; Sun, F.; Tan, B.C. The mitochondrion-targeted PENTATRICOPEPTIDE REPEAT78 protein is required for nad5 mature mRNA stability and seed development in maize. Mol. Plant 2017, 10, 1321-1333. [CrossRef] [PubMed]

73. Gutierrez-Marcos, J.F.; Dal Pra, M.; Giulini, A.; Costa, L.M.; Gavazzi, G.; Cordelier, S.; Sellam, O.; Tatout, C.; Paul, W.; Perez, P.; et al. Empty pericarp 4 encodes a mitochondrion-targeted pentatricopeptide repeat protein necessary for seed development and plant growth in maize. Plant Cell 2007, 19, 196-210. [CrossRef] [PubMed]

74. Liu, Y.J.; Xiu, Z.H.; Meeley, R.; Tan, B.C. Empty pericarp5 encodes a pentatricopeptide repeat protein that is required for mitochondrial RNA editing and seed development in maize. Plant Cell 2013, 25, 868-883. [CrossRef] [PubMed]

75. Sun, F.; Wang, X.M.; Bonnard, G.; Shen, Y.; Xiu, Z.H.; Li, X.J.; Gao, D.H.; Zhang, Z.H.; Tan, B.C. Empty pericarp7 encodes a mitochondrial E-subgroup pentatricopeptide repeat protein that is required for $c c m F_{N}$ editing, mitochondrial function and seed development in maize. Plant J. 2015, 84, 283-295. [CrossRef]

76. Sun, F.; Zhang, X.Y.; Shen, Y.; Wang, H.C.; Liu, R.; Wang, X.M.; Gao, D.H.; Yang, Y.Z.; Liu, Y.W.; Tan, B.C. The pentatricopeptide repeat protein EMPTY PERICARP8 is required for the splicing of three mitochondrial introns and seed development in maize. Plant J. 2018, 95, 919-932. [CrossRef]

77. Yang, Y.Z.; Ding, S.; Wang, H.C.; Sun, F.; Huang, W.L.; Song, S.; Xu, C.H.; Tan, B.C. The pentatricopeptide repeat protein EMP9 is required for mitochondrial $c \mathrm{cmB}$ and rps4 transcript editing, mitochondrial complex biogenesis and seed development in maize. New Phytol. 2017, 214, 782-795. [CrossRef]

78. Cai, M.J.; Li, S.Z.; Sun, F.; Sun, Q.; Zhao, H.L.; Ren, X.M.; Zhao, Y.X.; Tan, B.C.; Zhang, Z.X.; Qiu, F.Z. Emp10 encodes a mitochondrial PPR protein that affects the cis-splicing of nad2 intron 1 and seed development in maize. Plant J. 2017, 91, 132-144. [CrossRef]

79. Ren, X.M.; Pan, Z.Y.; Zhao, H.L.; Zhao, J.L.; Cai, M.J.; Li, J.; Zhang, Z.X.; Qiu, F.Z. EMPTY PERICARP11 serves as a factor for splicing of mitochondrial nad1 intron and is required to ensure proper seed development in maize. J. Exp. Bot. 2017, 68, 4571-4581. [CrossRef]

80. Sun, F.; Xiu, Z.H.; Jiang, R.C.; Liu, Y.W.; Zhang, X.Y.; Yang, Y.Z.; Li, X.J.; Zhang, X.; Wang, Y.; Tan, B.C. The mitochondrial pentatricopeptide repeat protein EMP12 is involved in the splicing of three nad2 introns and seed development in maize. J. Exp. Bot. 2019, 70, 963-972. [CrossRef] [PubMed]

81. Huang, J.; Lu, G.; Liu, L.; Raihan, M.S.; Xu, J.T.; Jian, L.M.; Zhao, L.X.; Tran, T.M.; Zhang, Q.H.; Liu, J.; et al. The kernel size-related quantitative trait locus qKW9 encodes a pentatricopeptide repeat protein that affects photosynthesis and grain filling. Plant Physiol. 2020, 183, 1696-1709. [CrossRef]

82. Xiu, Z.H.; Sun, F.; Shen, Y.; Zhang, X.Y.; Jiang, R.C.; Bonnard, G.; Zhang, J.H.; Tan, B.C. EMPTY PERICARP16 is required for mitochondrial nad2 intron 4 cis-splicing, complex I assembly and seed development in maize. Plant J. 2016, 85, 507-519. [CrossRef]

83. Wang, Y.; Liu, X.Y.; Huang, Z.Q.; Li, Y.Y.; Yang, Y.Z.; Sayyed, A.; Sun, F.; Gu, Z.Q.; Wang, X.M.; Tan, B.C. PPR-DYW protein EMP17 is required for mitochondrial RNA editing, complex III biogenesis, and seed development in maize. Front. Plant Sci. 2021, $12,693272$.

84. Li, X.L.; Huang, W.L.; Yang, H.H.; Jiang, R.C.; Sun, F.; Wang, H.C.; Zhao, J.; Xu, C.H.; Tan, B.C. EMP18 functions in mitochondrial atp 6 and cox 2 transcript editing and is essential to seed development in maize. New Phytol. 2019, 221, 896-907. [CrossRef] [PubMed]

85. Wang, Y.; Liu, X.Y.; Yang, Y.Z.; Huang, J.; Sun, F.; Lin, J.S.; Gu, Z.Q.; Sayyed, A.; Xu, C.H.; Tan, B.C. Empty Pericarp21 encodes a novel PPR-DYW protein that is required for mitochondrial RNA editing at multiple sites, complexes I and V biogenesis, and seed development in maize. PLoS Genet. 2019, 15, e1008305. [CrossRef]

86. Yang, Y.Z.; Ding, S.; Liu, X.Y.; Tang, J.J.; Wang, Y.; Sun, F.; Xu, C.H.; Tan, B.C. EMP32 is required for the cis-splicing of nad7 intron 2 and seed development in maize. RNA Biol. 2021, 18, 499-509. [CrossRef]

87. Ren, Z.J.; Fan, K.J.; Fang, T.; Zhang, J.J.; Yang, L.; Wang, J.H.; Wang, G.Y.; Liu, Y.J. Maize Empty pericarp602 encodes a P-type PPR protein that is essential for seed development. Plant Cell Physiol. 2019, 60, 1734-1746. [CrossRef] 
88. Fan, K.J.; Ren, Z.J.; Zhang, X.F.; Liu, Y.; Fu, J.J.; Qi, C.L.; Tatar, W.; Rasmusson, A.G.; Wang, G.Y.; Liu, Y.J. The pentatricopeptide repeat protein EMP603 is required for the splicing of mitochondrial Nad1 intron 2 and seed development in maize. J. Exp. Bot. 2021, erab339. [CrossRef] [PubMed]

89. Wang, H.C.; Chen, Z.L.; Yang, Y.Z.; Sun, F.; Ding, S.; Li, X.L.; Xu, C.H.; Tan, B.C. PPR14 interacts with PPR-SMR1 and CRM protein Zm-mCSF1 to facilitate mitochondrial intron splicing in maize. Front. Plant Sci. 2020, 11, 732. [CrossRef]

90. Liu, R.; Cao, S.K.; Sayyed, A.; Xu, C.H.; Sun, F.; Wang, X.M.; Tan, B.C. The mitochondrial pentatricopeptide repeat protein PPR18 is required for the cis-splicing of nad4 intron 1 and essential to seed development in maize. Int. J. Mol. Sci. 2020, $21,4047$.

91. Liu, R.; Cao, S.K.; Sayyed, A.; Yang, H.H.; Zhao, J.; Wang, X.M.; Jia, R.X.; Sun, F.; Tan, B.C. The DYW-subgroup pentatricopeptide repeat protein PPR27 functions on editing of multiple mitochondrial transcripts and interacts with ZmMORF1 in maize. J. Exp. Bot. 2020, 71, 5495-5505. [CrossRef] [PubMed]

92. Yang, H.H.; Xiu, Z.H.; Wang, L.; Cao, S.K.; Li, X.L.; Sun, F.; Tan, B.C. Two pentatricopeptide repeat proteins are required for the splicing of nad5 introns in maize. Front. Plant Sci. 2020, 11, 732. [CrossRef]

93. Chen, Z.L.; Wang, H.C.; Shen, J.Y.; Sun, F.; Wang, M.D.; Xu, C.H.; Tan, B.C. PPR-SMR1 is required for the splicing of multiple mitochondrial introns, interacts with Zm-mCSF1, and is essential for seed development in maize. J. Exp. Bot. 2019, 70, 5245-5258. [CrossRef]

94. Sosso, D.; Canut, M.; Gendrot, G.; Dedieu, A.; Chambrier, P.; Barkan, A.; Consonni, G.; Rogowsky, P.M. PPR8522 encodes a chloroplast-targeted pentatricopeptide repeat protein necessary for maize embryogenesis and vegetative development. J. Exp. Bot. 2012, 63, 5843-5857. [CrossRef]

95. Yuan, N.N.; Wang, J.C.; Zhou, Y.; An, D.; Xiao, Q.; Wang, W.Q.; Wu, Y.R. EMB-7L is required for embryogenesis and plant development in maize involved in RNA splicing of multiple chloroplast genes. Plant Sci. 2019, 287, 110203. [CrossRef] [PubMed]

96. De Longevialle, A.F.; Meyer, E.H.; Andres, C.; Taylor, N.L.; Lurin, C.; Millar, A.H.; Small, I.D. The pentatricopeptide repeat gene OTP43 is required for trans-splicing of the mitochondrial nad1 intron 1 in Arabidopsis thaliana. Plant Cell 2007, 19, 3256-3265. [CrossRef]

97. Lee, K.; Han, J.H.; Park, Y.I.; Colas des Francs-Small, C.; Small, I.; Kang, H. The mitochondrial pentatricopeptide repeat protein PPR19 is involved in the stabilization of NADH dehydrogenase 1 transcripts and is crucial for mitochondrial function and Arabidopsis thaliana development. New Phytol. 2017, 215, 202-216. [CrossRef] [PubMed]

98. Sun, Y.; Huang, J.Y.; Zhong, S.; Gu, H.Y.; He, S.; Qu, L.J. Novel DYW-type pentatricopeptide repeat (PPR) protein BLX controls mitochondrial RNA editing and splicing essential for early seed development of Arabidopsis. J. Genet. Genom. 2018, 45, 155-168. [CrossRef]

99. Lu, Y.Q.; Li, C.; Wang, H.; Chen, H.; Berg, H.; Xia, Y.J. AtPPR2, an Arabidopsis pentatricopeptide repeat protein, binds to plastid $23 \mathrm{~S}$ rRNA and plays an important role in the first mitotic division during gametogenesis and in cell proliferation during embryogenesis. Plant J. 2011, 67, 13-25. [CrossRef]

100. Wang, X.W.; An, Y.Q.; Qi, Z.; Xiao, J.W. PPR protein early chloroplast development 2 is essential for chloroplast development at the early stage of Arabidopsis development. Plant Sci. 2021, 308, 110908. [CrossRef]

101. Aryamanesh, N.; Ruwe, H.; Sanglard, L.V.P.; Eshraghi, L.; Bussell, J.D.; Howell, K.A.; Small, I.; Colas des Francs-Small, C. The pentatricopeptide repeat protein EMB2654 is essential for trans-splicing of a chloroplast small ribosomal subunit transcript. Plant Physiol. 2017, 173, 1164-1176. [CrossRef] [PubMed]

102. Marchetti, F.; Cainzos, M.; Shevtsov, S.; Córdoba, J.P.; Sultan, L.D.; Brennicke, A.; Takenaka, M.; Pagnussat, G.; Ostersetzer-Biran, O.; Zabaleta, E. Mitochondrial pentatricopeptide repeat protein, EMB2794, plays a pivotal role in NADH dehydrogenase subunit nad2 mRNA maturation in Arabidopsis thaliana. Plant Cell Physiol. 2020, 61, 1080-1094. [CrossRef] [PubMed]

103. Ding, Y.H.; Liu, N.Y.; Tang, Z.S.; Liu, J.; Yang, W.C. Arabidopsis GLUTAMINE-RICH PROTEIN23 is essential for early embryogenesis and encodes a novel nuclear PPR motif protein that interacts with RNA polymerase II subunit III. Plant Cell 2006, 18, 815-830. [CrossRef] [PubMed]

104. Zhao, P.; Wang, F.; Li, N.; Shi, D.Q.; Yang, W.C. Pentatricopeptide repeat protein MID1 modulates nad2 intron 1 splicing and Arabidopsis development. Sci Rep. 2020, 10, 2008. [CrossRef] [PubMed]

105. Zhang, J.; Xiao, J.W.; Li, Y.Q.; Su, B.D.; Xu, H.M.; Shan, X.Y.; Song, C.W.; Xie, J.B.; Li, R.L. PDM3, a pentatricopeptide repeatcontaining protein, affects chloroplast development. J. Exp. Bot. 2017, 68, 5615-5627. [CrossRef]

106. Zhang, L.; Qi, Y.Z.; Wu, M.M.; Zhao, L.; Zhao, Z.C.; Lei, C.L.; Hao, Y.Y.; Yu, X.W.; Sun, Y.L.; Zhang, X.; et al. Mitochondriontargeted PENTATRICOPEPTIDE REPEAT5 is required for cis-splicing of nad4 intron 3 and endosperm development in rice. Crop J. 2021, 9, 282-296. [CrossRef]

107. Leu, K.C.; Hsieh, M.H.; Wang, H.J.; Hsieh, H.L.; Jauh, G.Y. Distinct role of Arabidopsis mitochondrial P-type pentatricopeptide repeat protein-modulating editing protein, PPME, in nad1 RNA editing. RNA Biol. 2016, 13, 593-604. [CrossRef]

108. Small, I.D.; Schallenberg-Rudinger, M.; Takenaka, M.; Mireau, H.; Ostersetzer-Biran, O. Plant organellar RNA editing: What 30 years of research has revealed. Plant J. 2020, 101, 1040-1056. [CrossRef] [PubMed]

109. Blanc, V.; Litvak, S.; Araya, A. RNA editing in wheat mitochondria proceeds by a deamination mechanism. FEBS Lett. 1995, 373, 56-60. [CrossRef]

110. Bhattacharya, S.; Navaratnam, N.; Morrison, J.R.; Scott, J.; Taylor, W.R. Cytosine nucleoside/nucleotide deaminases and apolipoprotein B mRNA editing. Trends Biochem. Sci. 1994, 19, 105-106. [CrossRef] 
111. Boussardon, C.; Avon, A.; Kindgren, P.; Bond, C.S.; Challenor, M.; Lurin, C.; Small, I. The cytidine deaminase signature $\mathrm{HxE}(\mathrm{x})_{\mathrm{n}} \mathrm{CxxC}$ of DYW1 binds zinc and is necessary for RNA editing of $n d h D-1$. New Phytol. 2014, 203, 1090-1095. [CrossRef]

112. Hayes, M.L.; Dang, K.N.; Diaz, M.F.; Mulligan, R.M. A conserved glutamate residue in the C-terminal deaminase domain of pentatricopeptide repeat proteins is required for RNA editing activity. J. Biol. Chem. 2015, 290, 10136-10142. [CrossRef] [PubMed]

113. Oldenkott, B.; Yang, Y.Y.; Lesch, E.; Knoop, V.; Schallenberg-Rüdinger, M. Plant-type pentatricopeptide repeat proteins with a DYW domain drive C-to-U RNA editing in Escherichia coli. Commun. Biol. 2019, 2, 85. [CrossRef] [PubMed]

114. Hayes, M.L.; Santibanez, P.I. A plant pentatricopeptide repeat protein with a DYW-deaminase domain is sufficient for catalyzing C-to-U RNA editing in vitro. J. Biol. Chem. 2020, 295, 3497-3505. [CrossRef] [PubMed]

115. Takenaka, M.; Takenaka, S.; Barthel, T.; Frink, B.; Haag, S.; Verbitskiy, D.; Oldenkott, B.; Schallenberg-Rüdinger, M.; Feiler, C.G.; Weiss, M.S.; et al. DYW domain structures imply an unusual regulation principle in plant organellar RNA editing catalysis. Nat. Catal. 2021, 4, 510-522. [CrossRef]

116. Boussardon, C.; Salone, V.; Avon, A.; Berthomé, R.; Hammani, K.; Okuda, K.; Shikanai, T.; Small, I.; Lurin, C. Two interacting proteins are necessary for the editing of the NdhD-1 site in Arabidopsis plastids. Plant Cell 2012, 24, 3684-3694. [CrossRef] [PubMed]

117. Andres-Colas, N.; Zhu, Q.; Takenaka, M.; De Rybel, B.; Weijers, D.; Van Der Straeten, D. Multiple PPR protein interactions are involved in the RNA editing system in Arabidopsis mitochondria and plastids. Proc. Natl. Acad. Sci. USA 2017, 114, 8883-8888. [CrossRef] [PubMed]

118. Malbert, B.; Burger, M.; Lopez-Obando, M.; Baudry, K.; Launay-Avon, A.; Härtel, B.; Verbitskiy, D.; Jörg, A.; Berthomé, R.; Lurin, C.; et al. The analysis of the editing defects in the dyw2 mutant provides new clues for the prediction of RNA targets of Arabidopsis E+-class PPR proteins. Plants 2020, 9, 280. [CrossRef]

119. Guillaumot, D.; Lopez-Obando, M.; Baudry, K.; Avon, A.; Rigaill, G.; Falcon de Longevialle, A.; Broche, B.; Takenaka, M.; Berthomé, R.; De Jaeger, G.; et al. Two interacting PPR proteins are major Arabidopsis editing factors in plastid and mitochondria. Proc. Natl. Acad. Sci. USA 2017, 114, 8877-8882. [CrossRef]

120. Bentolila, S.; Heller, W.P.; Sun, T.; Babina, A.M.; Friso, G.; van Wijk, K.J.; Hanson, M.R. RIP1, a member of an Arabidopsis protein family, interacts with the protein RARE1 and broadly affects RNA editing. Proc. Natl. Acad. Sci. USA 2012, 109, e1453-e1461. [CrossRef]

121. Härtel, B.; Zehrmann, A.; Verbitskiy, D.; van der Merwe, J.A.; Brennicke, A.; Takenaka, M. MEF10 is required for RNA editing at nad2-842 in mitochondria of Arabidopsis thaliana and interacts with MORF8. Plant Mol. Biol. 2013, 81, 337-346. [CrossRef]

122. Brehme, N.; Bayer-Császár, E.; Glass, F.; Takenaka, M. The DYW subgroup PPR protein MEF35 targets RNA editing sites in the mitochondrial rpl16, nad4 and cob mRNAs in Arabidopsis thaliana. PLoS ONE 2015, 10, e0140680. [CrossRef]

123. Barkan, A.; Rojas, M.; Fujii, S.; Yap, A.; Chong, Y.S.; Bond, C.S.; Small, I. A combinatorial amino acid code for RNA recognition by pentatricopeptide repeat proteins. PLoS Genet. 2012, 8, e1002910. [CrossRef]

124. Huang, C.; Li, Z.R.; Yu, Q.B.; Ye, L.S.; Cui, Y.L.; Molloy, D.P.; Yang, Z.N. MORF2 tightly associates with MORF9 to regulate chloroplast RNA editing in Arabidopsis. Plant Sci. 2019, 278, 64-69. [CrossRef]

125. Yan, J.J.; Zhang, Q.X.; Guan, Z.Y.; Wang, Q.; Li, L.; Ruan, F.Y.; Lin, R.C.; Zou, T.T.; Yin, P. MORF9 increases the RNA-binding activity of PLS-type pentatricopeptide repeat protein in plastid RNA editing. Nat. Plants 2017, 3, 17037. [CrossRef]

126. Brown, G.G.; Colas des Francs-Small, C.; Ostersetzer-Biran, O. Group II intron splicing factors in plant mitochondria. Front. Plant Sci. 2014, 5, 35. [CrossRef] [PubMed]

127. Schmitz-Linneweber, C.; Lampe, M.K.; Sultan, L.D.; Ostersetzer-Biran, O. Organellar maturases: A window into the evolution of the spliceosome. Biochim. Biophys. Acta BBA Bioenerg. 2015, 1847, 798-808. [CrossRef]

128. Colas des Francs-Small, C.; Falcon de Longevialle, A.; Li, Y.H.; Lowe, E.; Tanz, S.K.; Smith, C.; Bevan, M.W.; Small, I. The pentatricopeptide repeat proteins TANG2 and ORGANELLE TRANSCRIPT PROCESSING439 are involved in the splicing of the multipartite nad5 transcript encoding a subunit of mitochondrial complex I. Plant Physiol. 2014, 165, 1409-1416. [CrossRef] [PubMed]

129. Hsieh, W.Y.; Liao, J.C.; Chang, C.Y.; Harrison, T.; Boucher, C.; Hsieh, M.H. The SLOW GROWTH3 pentatricopeptide repeat protein is Required for the splicing of mitochondrial NADH dehydrogenase subunit7 intron 2 in Arabidopsis. Plant Physiol. 2015, 168, 490-501. [CrossRef] [PubMed]

130. Haïli, N.; Planchard, N.; Arnal, N.; Quadrado, M.; Vrielynck, N.; Dahan, J.; Colas des Francs-Small, C.; Mireau, H. The MTL1 pentatricopeptide repeat protein is required for both translation and splicing of the mitochondrial NADH DEHYDROGENASE SUBUNIT7 mRNA in Arabidopsis. Plant Physiol. 2016, 170, 354-366. [CrossRef] [PubMed]

131. Xiu, Z.H.; Peng, L.; Wang, Y.; Yang, H.H.; Sun, F.; Wang, X.M.; Cao, S.K.; Jiang, R.C.; Wang, L.; Chen, B.Y.; et al. Empty pericarp24 and Empty pericarp 25 are required for the splicing of mitochondrial introns, complex I assembly, and seed development in maize. Front. Plant Sci. 2020, 11, 608550. [CrossRef] [PubMed]

132. Hao, Y.Y.; Wang, Y.L.; Wu, M.M.; Zhu, X.P.; Teng, X.; Sun, Y.L.; Zhu, J.P.; Zhang, Y.Y.; Jing, R.N.; Lei, J.; et al. The nuclear-localized PPR protein OsNPPR1 is important for mitochondrial function and endosperm development in rice. J. Exp. Bot. 2019, 70, 4705-4720. [CrossRef]

133. Wu, M.M.; Ren, Y.L.; Cai, M.H.; Wang, Y.L.; Zhu, S.S.; Zhu, J.P.; Hao, Y.Y.; Teng, X.; Zhu, X.P.; Jing, R.N.; et al. Rice FLOURY ENDOSPERM 10 encodes a pentatricopeptide repeat protein that is essential for the trans-splicing of mitochondrial nad1 intron 1 and endosperm development. New Phytol. 2020, 223, 736-750. [CrossRef] [PubMed] 
134. Xue, M.Y.; Liu, L.L.; Yu, Y.F.; Zhu, J.P.; Gao, H.; Wang, Y.H.; Wan, J.M. Lose-of-function of a rice nucleolus-localized pentatricopeptide repeat protein is responsible for the floury endosperm14 mutant phenotypes. Rice 2019, 12, 100. [CrossRef] [PubMed]

135. Weißenberger, S.; Soll, J.; Carrie, C. The PPR protein SLOW GROWTH 4 is involved in editing of nad4 and affects the splicing of nad2 intron 1. Plant Mol. Biol. 2016, 93, 355-368. [CrossRef]

136. Ichinose, M.; Tasaki, E.; Sugita, C.; Sugita, M. A PPR-DYW protein is required for splicing of a group II intron of cox1 pre-mRNA in Physcomitrella patens. Plant J. 2012, 70, 271-278. [CrossRef]

137. Schmitz-Linneweber, C.; Williams-Carrier, R.E.; Williams-Voelker, P.M.; Kroeger, T.S.; Vichas, A.; Barkan, A. A pentatricopeptide repeat protein facilitates the trans-splicing of the maize chloroplast rps12 pre-mRNA. Plant Cell 2006, 18, 2650-2663. [CrossRef]

138. Tadini, L.; Ferrari, R.; Lehniger, M.K.; Mizzotti, C.; Moratti, F.; Resentini, F.; Colombo, M.; Costa, A.; Masiero, S.; Pesaresi, P. Trans-splicing of plastid rps12 transcripts, mediated by AtPPR4, is essential for embryo patterning in Arabidopsis thaliana. Planta 2018, 248, 257-265. [CrossRef] [PubMed]

139. Ostheimer, G.J.; Williams-Carrier, R.; Belcher, S.; Osborne, E.; Gierke, J.; Barkan, A. Group II intron splicing factors derived by diversification of an ancient RNA-binding domain. EMBO J. 2003, 22, 3919-3929. [CrossRef]

140. Jenkins, B.D.; Barkan, A. Recruitment of a peptidyl-tRNA hydrolase as a facilitator of group II intron splicing in chloroplasts. EMBO J. 2001, 20, 872-879. [CrossRef]

141. Asakura, Y.; Galarneau, E.; Watkins, K.P.; Barkan, A.; van Wijk, K.J. Chloroplast RH3 DEAD Box RNA helicases in maize and Arabidopsis function in splicing of specific group II introns and affect chloroplast ribosome biogenesis. Plant Physiol. 2012, 159, 961-974. [CrossRef] [PubMed]

142. Wang, C.D.; Aubé, F.; Quadrado, M.; Dargel-Graffin, C.; Mireau, H. Three new pentatricopeptide repeat proteins facilitate the splicing of mitochondrial transcripts and complex I biogenesis in Arabidopsis. J. Exp. Bot. 2018, 69, 5131-5140. [CrossRef] [PubMed]

143. Wang, C.; Fourdin, R.; Quadrado, M.; Dargel-Graffin, C.; Tollete, D. Rerouting of ribosomal proteins into splicing in plant organelles. Proc. Natl. Acad. Sci. USA 2020, 117, 29979-29987. [CrossRef] [PubMed]

144. Khrouchtchova, A.; Monde, R.A.; Barkan, A. A short PPR protein required for the splicing of specific group II introns in angiosperm chloroplasts. RNA 2012, 18, 1197-1209. [CrossRef] [PubMed]

145. Ke, J.Y.; Chen, R.Z.; Ban, T.; Zhou, X.E.; Gu, X.; Tan, M.H.E.; Chen, C.; Kang, Y.Y.; Brunzelle, J.S.; Zhu, J.K.; et al. Structural basis for RNA recognition by a dimeric PPR-protein complex. Nat. Struct. Mol. Biol. 2013, 20, 1377-1382. [CrossRef] [PubMed]

146. Lee, K.; Park, S.J.; Colas des Francs-Small, C.; Whitby, M.; Small, I.; Kang, H. The coordinated action of PPR4 and EMB 2654 on each intron half mediates trans-splicing of rps12 transcripts in plant chloroplasts. Plant J. 2019, 100, 1193-1207. [CrossRef]

147. Fedorova, O.; Solem, A.; Pyle, A.M. Protein-facilitated folding of group II intron ribozymes. J. Mol. Biol. 2010, 397, 799-813. [CrossRef]

148. Yan, J.J.; Yao, Y.Y.; Hong, S.X.; Yang, Y.; Shen, C.C.; Zhang, Q.X.; Zhang, D.L.; Zou, T.T.; Yin, P. Delineation of pentatricopeptide repeat codes for target RNA prediction. Nucleic Acids Res. 2019, 47, 3728-3738. [CrossRef] [PubMed] 